\title{
APPLICATION OF PERFORMANCE INDICATORS TO A UNIVERSITY HOSPITAL
}

\author{
İsmail YILDIZ ${ }^{1}$, Eylem Can ÖZDEMIR ${ }^{2}$, Funda KAYMAZ ${ }^{2}$,Zeynep YILDIZ ${ }^{2}$, Velat ŞEN ${ }^{2}$ \\ ${ }^{1}$ Dicle University, Faculty of Medicine, Department of Biostatistics, Diyarbakır/Turkey, \\ iyildiz21@yahoo.com \\ ${ }^{2}$ Hospital of Dicle University,Quality and Strategy Development Office, Diyarbakır/Turkey \\ hastanekalite@dicle.edu.tr
}

\begin{abstract}
Assessment" is the process of objectively understanding the state or condition of a thing, by observation and measurement. Assessment of something means taking a measure of its effectiveness. "Formative" assessment is measurement for the purpose of improving it. "Summative" assessment is what we normally call "evaluation." Evaluation" is the process of observing and measuring a thing for the purpose of judging it and of determining its "value," either by comparison to similar things, or to a standard. Although health service can be provided in different structures and systems the common goal in all health care services is to practice the right procedures on the right people at the right time. This may be possible with the continuous improvement process of quality and development.

In this study we emphasized on 19 indicators followed in Dicle University Hospital regarding targets, obtained results, interpretation of results, corrective and preventive actions, challenges and solutions for collecting correct data. Additionally by taking account indicator applications in Dicle University a model was proposed for university hospitals.
\end{abstract}

Key words: Assessment, evaluation, performance, indicator, model

\section{INTRODUCTION:}

Indicator is a way to measure, indicate, point out or point to with more or less exactness. It is something that is a sign, symptom or index of or used to show visually the condition of a system.

In quality management decisions must be based on proofs and data. Quality, efficiency, effectiveness, transparency and planning of health services can take place only by measuring results of followed and evaluated data. It can be said that quality and measurement are indispensable in evaluation of health services.

Quality indicator is a systematic measurement tool in order to monitor specific activities as part of the quality management system. In recent days indicator targets are used to reduce morbidity, complications, errors and adverse events in health services. In health care as in other arenas which cannot be measured is difficult to improve. Reliable indicators should be used in order to improve the quality of health care by providers, consumers and policy makers and others seeking to improve the [1-4]. Measurement is central to the concept of hospital quality improvement; it provides a means to define what hospitals actually do, and to compare that with the original targets in order to identify 
opportunities for improvement [5-7]. The principal methods of measuring hospital performance are regulatory inspection, public satisfaction surveys, third-party assessment, and statistical indicators, most of which have never been tested rigorously [8].

Ministry of Health in Turkey determined 19 quality performance indicators and asked health institutions to follow process of indicators. It has become a necessity to enter data within the Indicator Management System (IMS) by Health Ministry of Turkey [9].

At the end of 2014 a Performance Indicator Data Analysis was carried out by Dicle University Quality and Strategy Development Coordinator and it was investigated that affiliated branches and affiliated departments had not enter efficient and enough data.

The Indicator Management Working Group was formed upon this. Indicator Management Working Group gathered during certain periods and decided on 2015 Indicator Targets and 2014 data analysis such as:

$\checkmark$ Realizing of Corrective and Preventive Activities related to low or high targets,

$\checkmark$ Researching and Selecting University hospitals equivalent to our hospital as a partner in comparison,

$\checkmark$ Determining 2015 targets

$\checkmark$ Sharing 2015 indicator targets with related committees,

$\checkmark$ Sending official letters to the responsible of units concerned about inaccessible data in 2014

$\checkmark$ Sharing results of performance indicator targets of 2014

In the framework of these decisions a module called Indicator Management was developed on Hospital Information Management System and information about module was given to all units.

\section{FINDINGS:}

According to the results of the analysis conducted by the Indicator Management Module, the following findings were obtained. In Tables 1- 19 targets and results of 2014, and targets of 2015 regarding indicators is given. Also target of the indicator is defined and source of data, responsible for collecting data and following the process is indicated in the tables.

Table 1: Indicator of injuries resulted from cutting and drilling

\begin{tabular}{|l|l|}
\hline Units to be followed & Hospital's all polyclinics and clinics \\
\hline Target of Indicator & $\begin{array}{l}\text { Following and evaluating frequency, type and reasons of cutter drill injuries. } \\
\text { After injuries resulted from cutting and drilling person who is exposed to } \\
\text { blood or other body fluids may get effected. In order to reduce these risks } \\
\text { necessary measures must be taken. }\end{array}$ \\
\hline Source of Data & Notification form of injuries resulted from cutting and drilling \\
\hline Frequency of Data Collecting & Monthly \\
\hline Responsible(s) & $\begin{array}{l}\text { Responsible nurse for infection control } \\
\text { Committee of occupational health, } \\
\text { Quality Strategy Development Coordinator }\end{array}$ \\
\hline $\mathbf{2 0 1 4}$ Target & \multicolumn{2}{|c|}{$\mathbf{2 0 1 4}$ Results } & $\mathbf{2 0 1 5}$ Target \\
\hline \% 1 & \%1,36 1 \\
\hline
\end{tabular}


According to Table 1. After comparing determined target and reached results it was seen that targets were realized. It can be said that patient safety in hospital increased in last year.

Table 2.Indicator of number of health workers exposed to blood and other body fluids

\begin{tabular}{|l|l|l|}
\hline Units to be followed & All of hospital's areas of investigation and treatment. \\
\hline Target of Indicator & $\begin{array}{l}\text { Following frequency, type and reasons of being exposed to blood and other } \\
\text { body fluids. } \\
\text { After being exposed to blood and other body fluids a person may be affected. } \\
\text { In order to reduce these risks necessary measures must be taken. }\end{array}$ \\
\hline Source of Data & Notification form of being exposed to blood and other body fluids \\
\hline Frequency of Data Collecting & Once in 3 Months \\
\hline Responsible(s) & $\begin{array}{l}\text { Responsible nurse for infection control } \\
\text { Committee of occupational health, } \\
\text { Quality Strategy Development Coordinator }\end{array}$ \\
\hline \multicolumn{2}{|c|}{$\mathbf{2 0 1 4}$ Results } & $\mathbf{2 0 1 5}$ Target \\
\hline \% 1 & \multicolumn{2}{|c|}{$\mathbf{0 . 0 6}$} \\
\hline
\end{tabular}

Table 2 shows that since the results of 2014 are below the targets planned for that year we can say that efforts served the purpose in that period.

Table 3. Indicator of intensive care mortality rates

\begin{tabular}{|c|c|c|}
\hline Units to be followed & \multicolumn{2}{|c|}{ Intensive care units of hospital } \\
\hline Target of Indicator & \multicolumn{2}{|c|}{$\begin{array}{l}\text { Following intensive care mortality rates and taking measures in order to } \\
\text { reduce mortality }\end{array}$} \\
\hline Source of Data & \multicolumn{2}{|c|}{ Notification form of Intensive Care Mortality Rates } \\
\hline Frequency of Data Collecting & \multicolumn{2}{|l|}{ Monthly } \\
\hline Responsible(s) & \multicolumn{2}{|c|}{$\begin{array}{l}\text { Responsible of Intensive Care unit, } \\
\text { Committee of Patient safety }\end{array}$} \\
\hline 2014 Target & 2014 Result & 2015 Target \\
\hline$\% 8$ & $\% 10.92$ & $\% 5$ \\
\hline
\end{tabular}

Results regarding mortality rates are over the targets for 2014. As our hospital is serving to a very wide range of patients, this result does not affect patient safety. 
IJHSRP volume 1 Issue 12016

International Journal of Health Science Research and Policy

Table 4. Indicator of decubitus ulcer in Intensive Care Units

\begin{tabular}{|c|c|c|}
\hline Units to be followed & \multicolumn{2}{|l|}{ Intensive Care units of Hospital } \\
\hline Target of Indicator & \multicolumn{2}{|c|}{$\begin{array}{l}\text { Evaluating and enhancing quality of patient care in intensive care units and } \\
\text { taking measures about decubitus ulcer cases. }\end{array}$} \\
\hline Source of Data & \multicolumn{2}{|c|}{ Notification form of decubitus ulcer cases in Intensive Care Units } \\
\hline Frequency of Data Collecting & \multicolumn{2}{|l|}{ Monthly } \\
\hline Responsible(s) & \multicolumn{2}{|c|}{$\begin{array}{l}\text { Responsible of Intensive Care unit, } \\
\text { Committee of Patient safety } \\
\text { Quality and Strategy Development Coordinator }\end{array}$} \\
\hline 2014 Target & 2014 Result & 2015 Target \\
\hline $\begin{array}{l}\text { Incidence no }=\% 1 \\
\text { Total incidence rate }=\mathbf{\% 1}\end{array}$ & $\begin{array}{l}\text { Incidence no }=\% 0,78 \\
\text { Total incidence rate }=\mathbf{\% 0}, \mathbf{3 8}\end{array}$ & $\begin{array}{l}\text { Incidence no }=\% 1 \\
\text { Total incidence rate }=\% \mathbf{1}\end{array}$ \\
\hline
\end{tabular}

According to Table 4 results for 2014 are below targets of that year. It can be said that patient safety in intensive units increased in last year.

Table 5. Indicator of Hospital infection rate in intensive care units

\begin{tabular}{|c|c|c|}
\hline Units to be followed & \multicolumn{2}{|c|}{ Intensive Care units of Hospital } \\
\hline Target of Indicator & \multicolumn{2}{|c|}{$\begin{array}{l}\text { Hospital infection is a major problem in hospitals. Controlling and preventing } \\
\text { of this type of infection is very important. }\end{array}$} \\
\hline Source of Data & \multicolumn{2}{|c|}{ Notification form of infection rate in Intensive Care Units } \\
\hline Frequency of Data Collecting & \multicolumn{2}{|l|}{ Monthly } \\
\hline Responsible(s) & \multicolumn{2}{|c|}{$\begin{array}{l}\text { Responsible of Intensive Care unit, } \\
\text { Committee of Patient safety } \\
\text { Quality and Strategy Development Coordinator }\end{array}$} \\
\hline 2014 Target & 2014 Result & 2015 Target \\
\hline$\% 1.5$ & $\% 1,36$ & $\% 1.5$ \\
\hline
\end{tabular}

We can say that infection rate in intensive care units decreased in 2014 according to Table 4. Efforts of responsibles in intensive care units served the purpose of targets in that period. 
IJHSRPVolume 1 Issue 12016

International Journal of Health Science Research and Policy

Table 6. Indicator of Surgical Site Infection Rate

\begin{tabular}{|l|l|}
\hline Short Definition & $\begin{array}{l}\text { A measurement tool to follow the rate of infection in patients undergoing } \\
\text { surgery at the hospital. }\end{array}$ \\
\hline Target of Indicator & $\begin{array}{l}\text { To monitor and prevent surgical site infection rates in surgically treated } \\
\text { patients }\end{array}$ \\
\hline Source of Data & Data entered by infection nurse \\
\hline Frequency of Data Collecting & Once in 3 Months \\
\hline Responsible(s) & $\begin{array}{l}\text { Responsible nurse for Infection Control } \\
\text { Curse responsible for Surgery Unit } \\
\text { Quality and Strategy Development Coordinator }\end{array}$ \\
\hline 2014 Target & \multicolumn{2}{|c|}{$\mathbf{2 0 1 4}$ Result } & $\mathbf{2 0 1 5}$ Target \\
\hline
\end{tabular}

According to Table 6 results for 2014 are below targets of that yearon behalf ofsurgical site Infection Rate. This result contributed to reducing mortality and costs of health services.

Table 7. Indicator of Falling Patients

\begin{tabular}{|c|c|c|}
\hline Units to be followed & \multicolumn{2}{|c|}{ All of our hospital's areas of investigation and treatment. } \\
\hline Target of Indicator & \multicolumn{2}{|c|}{ Following and preventing patient falls in hospitals. } \\
\hline Source of Data & \multicolumn{2}{|c|}{ Notification form of Falling patient } \\
\hline Frequency of Data Collecting & \multicolumn{2}{|l|}{ Monthly } \\
\hline Responsible(s) & \multicolumn{2}{|c|}{$\begin{array}{l}\text { Responsible of the unit } \\
\text { Committee of Patient safety }\end{array}$} \\
\hline 2014 Target & 2014 Result & 2015 Target \\
\hline$\% 1$ & $\% 0.11$ & $\% 1$ \\
\hline
\end{tabular}

Table 7 shows that results of 2014 for Indicator of Falling Patients are below the target. Trainings regarding patient safety, and use of falling risk scales decreased the rate. 
IJHSRP volume 1 Issue 12016

International Journal of Health Science Research and Policy

Table 8.Indicator of Cesarean rates

\begin{tabular}{|c|c|}
\hline Short definition & Ratio of births by cesarean in total live births \\
\hline Target of Indicator & $\begin{array}{l}\text { High cesarean rates create risks in births and has disadvantages on behalf of } \\
\text { future pregnancies. Also it brings additional costs. So this rate has to be } \\
\text { reduced. }\end{array}$ \\
\hline Source of Data & Notification form of cesarean rates \\
\hline Frequency of Data Collecting & Monthly \\
\hline Responsible(s) & $\begin{array}{l}\text { Responsible nurse for Obstetrics Unit } \\
\text { Committee of Patient safety }\end{array}$ \\
\hline 2014 Target & 2015 Target \\
\hline$\% 50$ & $\% 78.20$ \\
\hline
\end{tabular}

According to Table 8, targets of Indicator of Cesarean rates couldn't be reached. After analysis it was found that this result arises from preference of patients.

Table 9. Indicator of rate of using operating table in surgeries

\begin{tabular}{|c|c|}
\hline Short Definition & $\begin{array}{l}\text { A measurement tool for determining effective and efficient use of operating } \\
\text { tables in hospital. }\end{array}$ \\
\hline Target of Indicator & $\begin{array}{l}\text { Reducing waiting periods of patients and making use of hospital sources } \\
\text { efficient and effective on behalf of time and cost }\end{array}$ \\
\hline Source of Data & Notification form of rate of using operating table in surgeries \\
\hline Frequency of Data Collecting & Monthly \\
\hline Responsible(s) & $\begin{array}{l}\text { Responsible nurse for operating room } \\
\text { Responsible doctor }\end{array}$ \\
\hline 2014 Target & 2015 Target \\
\hline$\% 50$ & $\% 40.19$ \\
\hline
\end{tabular}

In Table 9 it can be seen that results of 2014 for Indicator of rate of using operating table in surgeries is are below the target. 
IJHSRP volume 1 Issue 12016

International Journal of Health Science Research and Policy

Table 10.Indicator of rehospitalization in intensive care units

\begin{tabular}{|c|c|}
\hline Short Definition & Rate of rehospitalization of discharged patients 48 hours after discharge \\
\hline Target of Indicator & $\begin{array}{l}\text { Evaluating and enhancing clinical efficiency of intensive care units and } \\
\text { providing safety of patients. }\end{array}$ \\
\hline Source of Data & Notification form of rehospitalization of discharged patients rates \\
\hline Frequency of Data Collecting & Monthly \\
\hline Responsible(s) & $\begin{array}{l}\text { Responsible of Intensive Care Unit } \\
\text { Committee of Patient safety }\end{array}$ \\
\hline 2014 Target & 2015 Target \\
\hline$\% 5$ & $\% 24.08$ \\
\hline
\end{tabular}

Although rate of rehospitalization in intensive care units seems to increase in Table 10 after analyzing the reasons, it was found that there was a deficiency in entering the data.

Table 11.Indicator of rate of patients who reapply emergency service in 24 hours

\begin{tabular}{|c|c|c|c|c|c|}
\hline \multicolumn{2}{|c|}{ Short Definition } & \multicolumn{4}{|c|}{$\begin{array}{l}\text { Determining and following the number and the rate of emergency patients who } \\
\text { reapply in } 24 \text { hours. Period begins in the first hour of patient's first application } \\
\text { and includes next } 24 \text { hours. }\end{array}$} \\
\hline \multicolumn{2}{|c|}{ Target of Indicator } & \multicolumn{4}{|c|}{$\begin{array}{l}\text { Determining and following the health services efficiency and patient care in } \\
\text { emergency unit. }\end{array}$} \\
\hline \multicolumn{2}{|c|}{ Source of Data } & \multicolumn{4}{|c|}{$\begin{array}{l}\text { Notification form of emergency patients who reapply emergency service } 24 \\
\text { hours }\end{array}$} \\
\hline \multicolumn{2}{|c|}{ Frequency of Data Collecting } & \multicolumn{4}{|l|}{ Monthly } \\
\hline \multicolumn{2}{|c|}{ Responsible(s) } & \multicolumn{4}{|c|}{$\begin{array}{l}\text { Emergency service response specialist } \\
\text { Responsible nurse of emergency } \\
\text { Committee of Patient Safety } \\
\text { Quality and Strategy Development Coordinator }\end{array}$} \\
\hline \multicolumn{2}{|c|}{2014 Target } & \multicolumn{2}{|c|}{2014 Result } & \multicolumn{2}{|c|}{2015 Target } \\
\hline $\begin{array}{l}\text { Emergency } \\
\text { for Adults }\end{array}$ & $\begin{array}{l}\text { Emergency } \\
\text { for } \\
\text { Children }\end{array}$ & $\begin{array}{l}\text { Emergency for } \\
\text { Adults }\end{array}$ & $\begin{array}{l}\text { Emergency for } \\
\text { Children }\end{array}$ & $\begin{array}{l}\text { Emergency for } \\
\text { Adults }\end{array}$ & $\begin{array}{l}\text { Emergency for } \\
\text { Children }\end{array}$ \\
\hline $\begin{array}{l}I W=\% 30 \\
O W=\% 50\end{array}$ & $\begin{array}{l}\mathrm{IW}=\% 30 \\
\mathrm{OW}=\% \mathbf{5 0}\end{array}$ & $\begin{array}{l}\mathrm{IW}=\% 34.73 \\
\mathrm{OW}=\% 65.42\end{array}$ & $\begin{array}{l}I W=\% 34.04 \\
O W=\% 65.96\end{array}$ & $\begin{array}{l}I W=\% 30 \\
\text { OW }=\% 50\end{array}$ & $\begin{array}{l}I W=\% 30 \\
O W=\% 50\end{array}$ \\
\hline
\end{tabular}

IW:In work hours

OW:Out of work hours

We can say that infection rate of emergency patients who reapply emergency service in 24 hours increased in 2014 according to Table 11. 
Table 12.Indicator of rate of dispatched patients to another health institution and distribution of diagnosis in emergency service

\begin{tabular}{|c|c|}
\hline Short Definition & $\begin{array}{l}\text { Evaluation of dispatched patients to another health institution and distribution } \\
\text { of diagnosis in emergency service by numbers and rates }\end{array}$ \\
\hline Target of Indicator & $\begin{array}{l}\text { Determining and following rate of dispatched patients to another health } \\
\text { institution and distribution of diagnosis in emergency service }\end{array}$ \\
\hline Source of Data & $\begin{array}{l}\text { Notification form of rate of dispatched patients to another health institution } \\
\text { and distribution of diagnosis in emergency service }\end{array}$ \\
\hline Frequency of Data Collecting & Monthly \\
\hline Responsible(s) & $\begin{array}{l}\text { Emergency service response specialist } \\
\text { Responsible nurse of emergency unit } \\
\text { Committee of Patient Safety }\end{array}$ \\
\hline 2014 Target & 2015 Target \\
\hline$\% 1$ & $\% 0.2$ \\
\hline
\end{tabular}

In Table 12 it can be seen that results of 2014 rate of dispatched patients to another health institution is below the target. This is a result of effective process in health services in our hospital.

Table 13.Indicators of staying time of patients in short stay units in emergency units

\begin{tabular}{|c|c|}
\hline Short Definition & Following staying time of patients in short stay units in emergency units \\
\hline Target of Indicator & $\begin{array}{l}\text { Promotion of efficiency and effectiveness of health services and providing } \\
\text { safety of patients in emergency services }\end{array}$ \\
\hline Source of Data & $\begin{array}{l}\text { Notification form of staying time of patients in short stay units in emergency } \\
\text { units }\end{array}$ \\
\hline Frequency of Data Collecting & Monthly \\
\hline Responsible(s) & $\begin{array}{l}\text { Responsible specialist in emergency service } \\
\text { Responsible nurse in emergency service } \\
\text { Responsible staff for data recording }\end{array}$ \\
\hline 2014 Target & 2015 Target \\
\hline$\% 5$ & $\% 5,58$ \\
\hline
\end{tabular}

According to Table 13 results for 2014 were more than target on behalf of staying time of patients in short stay units in emergency units. This result is related to insufficient data entering. 
Table 14. Indicator of reaching time of consultant doctor to emergency service in case of calling.

\begin{tabular}{|c|c|}
\hline Short Definition & $\begin{array}{l}\text { A measurement tool for investigating and following reaching time of } \\
\text { consultant doctor to emergency service in case of calling. }\end{array}$ \\
\hline Target of Indicator & $\begin{array}{l}\text { Promoting efficiency and effectiveness of emergency services and providing } \\
\text { safety of patients in emergency services }\end{array}$ \\
\hline Source of Data & $\begin{array}{l}\text { Notification form of reaching time of consultant doctor to emergency service } \\
\text { in case of calling. }\end{array}$ \\
\hline Frequency of Data Collecting & Monthly \\
\hline Responsible(s) & $\begin{array}{l}\text { Responsible specialist in emergency service } \\
\text { Committee of Patient Safety } \\
\text { Quality and Strategy Development Coordinator }\end{array}$ \\
\hline 2014 Target & 2015 Target \\
\hline$\% 95$ & No data \\
\hline
\end{tabular}

Table 15. Indicator of evaluation of consistency rate between Cytologic and Pathological diagnosis

\begin{tabular}{|c|c|}
\hline Short Definition & $\begin{array}{l}\text { A measurement tool in order to evaluate the consistency between Cytologic } \\
\text { and Pathological diagnosis of a patient. }\end{array}$ \\
\hline Target of Indicator & Developing efficiency of pathology laboratory and providing safety of patients \\
\hline Source of Data & $\begin{array}{l}\text { Notification form of rate of consistency between Cytologic and Pathological } \\
\text { diagnosis }\end{array}$ \\
\hline Frequency of Data Collecting & Monthly \\
\hline Responsible(s) & $\begin{array}{l}\text { Responsible nurse of Infection control } \\
\text { Committee of Patient Safety } \\
\text { Quality and Strategy Development Coordinator }\end{array}$ \\
\hline 2014 Target & 2014 Result \\
\hline$\% 95$ & No data \\
\hline
\end{tabular}


Table 16.Indicator of rate of Nurses' changing work place in the hospital

\begin{tabular}{|c|c|c|}
\hline Short Definition & \multicolumn{2}{|c|}{ A measurement tool for determining efficiency of nurses in health services. } \\
\hline Target of Indicator & \multicolumn{2}{|c|}{$\begin{array}{l}\text { Integrating nurses to process of treatment process and promoting efficiency of } \\
\text { health services. }\end{array}$} \\
\hline Source of Data & \multicolumn{2}{|c|}{ Notification form of Nurses' changing work place in the hospital } \\
\hline Frequency of Data Collecting & \multicolumn{2}{|l|}{ Once in a month } \\
\hline Responsible(s) & \multicolumn{2}{|c|}{$\begin{array}{l}\text { Head nurse } \\
\text { Human resources department }\end{array}$} \\
\hline 2014 Target & 2014 Result & 2015 Target \\
\hline$\% 1$ & No data & $\% 1$ \\
\hline
\end{tabular}

Table 17.Indicator for filling out inpatient care reports completely

\begin{tabular}{|c|c|}
\hline Short Definition & $\begin{array}{l}\text { A measurement tool for checking the reports of inpatients from examination } \\
\text { period to discharge }\end{array}$ \\
\hline Target of Indicator & Following and providing safety of records in patient records \\
\hline Source of Data & Notification form of inpatient care reports \\
\hline Frequency of Data Collecting & Monthly \\
\hline Responsible(s) & $\begin{array}{l}\text { Responsible nurse in the unit } \\
\text { Responsible staff for data recording } \\
\text { Archivist of unit } \\
\text { Quality and Strategy Development Coordinator }\end{array}$ \\
\hline 2014 Target & 2015 Target \\
\hline$\% 5$ & No data \\
\hline
\end{tabular}


Table 18. Indicator of rate of the number of polyclinic rooms per doctor

\begin{tabular}{|l|l|l|}
\hline Short Definition & $\begin{array}{l}\text { A measurement tool for determining and following the number of polyclinic } \\
\text { rooms per doctor }\end{array}$ \\
\hline Target of Indicator & $\begin{array}{l}\text { Providing a private room for every doctor in polyclinics and following the } \\
\text { efficiency of health services. }\end{array}$ \\
\hline Source of Data & Indicator of rate of polyclinic room per doctor \\
\hline Frequency of Data Collecting & Monthly \\
\hline Responsible(s) & $\begin{array}{l}\text { Chief Physician, } \\
\text { Quality and Strategy Development Coordinator }\end{array}$ \\
\hline $\mathbf{2 0 1 4}$ Target & $\mathbf{2 0 1 4 \text { Result }}$ & $\mathbf{2 0 1 5}$ Target \\
\hline$\% 10$ & No data & $\mathbf{2 1 0}$ \\
\hline
\end{tabular}

Table 19. Indicator for use of antibiotics in Surgical Prophylaxis

\begin{tabular}{|l|l|}
\hline Short Definition & $\begin{array}{l}\text { A measurement tool for controlling correct use of antibiotics in order to } \\
\text { prevent infections after surgeries. }\end{array}$ \\
\hline Target of Indicator & Preventing complications after surgical operations \\
\hline Source of Data & Notification form of use of antibiotics in Surgical Prophylaxis \\
\hline Frequency of Data Collecting & Monthly \\
\hline Responsible(s) & $\begin{array}{l}\text { Committee of Infection Control } \\
\text { Committee of Patient Safety } \\
\text { Quality and Strategy Development Coordinator }\end{array}$ \\
\hline $\mathbf{2 0 1 4}$ Target & \multicolumn{2}{|c|}{$\mathbf{2 0 1 4 \text { Result }}$} & $\mathbf{2 0 1 5}$ Target \\
\hline \% 80 & \multicolumn{2}{|c|}{$\mathbf{8 0}$} \\
\hline
\end{tabular}

\section{DISCUSSING AND CONCLUSION}

Measurement is central to the concept of quality improvement; it provides a means to define what hospitals actually do, and to compare that with the original targets in order to identify opportunities for improvement [5].

Evaluating 19 indicators according to data collected from units, we communicated with units, which didn't supply data. Reasons of lack of data were investigated and root-reason analysis was 
made. Make up for the shortcomings had been done about data input in units for 2015. For reaching goals we shared the results with Indicator management working group, Quality and Strategy Development Coordinator, Committee of Patient Safety and Committee of Occupational Health Group.

As a result we recommended that every university establish an Indicator Management Department. In order to establish an Indicator Management Department a module should be developed by responsible information management units of hospitals.

The proposed module type is in this form:

Table 20: Annual Hospital Indicator follow-up

\begin{tabular}{|c|c|c|c|c|c|}
\hline \multicolumn{5}{|c|}{ HOSPITAL ANNUAL INDICATOR MEASUREMENT FORM } \\
\hline Indicator name & Responsible & $\begin{array}{c}\text { Target of last } \\
\text { year }\end{array}$ & $\begin{array}{c}\text { Results of last } \\
\text { year }\end{array}$ & $\begin{array}{c}\text { Results of } \\
\text { equivalent } \\
\text { hospital for } \\
\text { last year }\end{array}$ & $\begin{array}{c}\text { Targets of next } \\
\text { year }\end{array}$ \\
\hline & & & & & \\
& & & & & \\
\hline
\end{tabular}

By this developed module it is obvious that responsible units should be educated and annual analysis should be done by Quality and Strategy Development Coordinator. After analysis Corrective preventive action form should be organized and followed for units that couldn't reach the targets of last year. Additionally every hospital should determine an equivalent university hospital in order to make comparisons. After analysis done at the end of the year, results should be compared by equivalent hospital. Corrective preventive action form should be organized and followed for units, which are below the results of equivalent hospital, and required improvements must be done.

\section{REFERENCES}

[1] ***, University of Albany, State University of New York, What is Difference between "assessment" and "evaluation", http://www.itlal.org/?q=node/93

[2] İnal, B B.,Quality Indicators in Medical Laboratory (In Turkish), Turkish Biochemical Society, Symposium of Laboratory Management, Malatya,Turkey2014 http://www.turkbiyokimyadernegi.org.tr/dosyalar/belgeler/kongre/malatya 2014/BERRIN BERC IK INAL.pdf

[3] Kohn Linda T, Corrigan Janet M, Donaldson Molla S. To Err Is Human: Building A Safer Health System. National Academy Press, Washington, DC., USA, 2000.

[4] Plebani $\mathrm{M}^{1}$, Chiozza ML, Sciacovelli L. Towards harmonization of quality indicators in laboratory medicine.Clin Chem Lab Med. 51(2013),1, pp:187-95 
IJHSRPVolume 1 Issue 12016

International Journal of Health Science Research and Policy

[5] ***, Republic of Turkey Ministry of Health,

https://kalite.saglik.gov.tr/content/files/duyurular_2011/2011/2014/indikatorkitabi_web.pdf

[6] ***, Turkish Quality Association, http://www.kalder.org/kalderhakkinda.aspx?id=6

[7] ***, Republic of Turkey Ministry of Health,

https://kalite.saglik.gov.tr/content/files/duyurular_2011/2011/2014/sks_hastane_versiyon_5_08.07 .2015.pdf (11.11.2015)

$[8]^{* * *}$, WHO, How can hospital performance be measured and monitored? http://www.euro.who.int/_data/assets/pdf_file/0009/74718/E82975.pdf

[9] ***,Republic of Turkey Ministry of Health, Institutional Performance And Quality Applications In Healthcare, Department of Performance Management and Quality Development http://www.kalite.saglik.gov.tr/Eklenti/4102,institualperformanceandqualityapplicationsinhealthca rtrceviripdf.pdf?0 